\title{
Islet amyloid polypeptide-like immunoreactivity in the islet $B$ cells of Type 2 (non-insulin-dependent) diabetic and non-diabetic individuals
}

\author{
P. Westermark ${ }^{1}$, E. Wilander ${ }^{1}$, G. T. Westermark ${ }^{1}$ and K. H. Johnson ${ }^{2}$ \\ ${ }^{1}$ Department of Pathology, University Hospital, Uppsala, Sweden and \\ ${ }^{2}$ Department of Veterinary Pathobiology, College of Veterinary Medicine, University of Minnesota, St. Paul, Minnesota, USA
}

\begin{abstract}
Summary. A novel peptide, islet amyloid polypeptide (IAPP), with structural resemblance to calcitonin gene-related peptide has recently been purified from amyloid deposits in an insulinoma and from islets of Langerhans. By immunohistochemical methods, using antisera to a synthetic undecapeptide of IAPP and to insulin, we show that freshly fixed islet B cells in man, guinea pig, rat, mouse and hamster exhibit strong IAPP-immunoreactivity while A cells are unreactive. In human autopsy material, all of 11 non-diabetic individuals had IAPP immunoreactivity of the islets. In comparison 8 of the 13 patients with Type 2 (non-insulin-dependent) diabetes had no IAPP immunoreactive cells. The proportion of islet cells having IAPP immunoreactivity exceeded $10 \%$ in only 1 of the 5 remaining diabetic patients while in all 13 patients substantially more than $10 \%$ of the islet cells contained immunoreactive insulin. IAPP-positive amyloid deposits were found in $20-99 \%$ of the islets in 12 of the Type 2 diabetic pat-
\end{abstract}

ients while 6 of 11 non-diabetic subjects had amyloid in $3-11 \%$ of their islets. In islets with IAPP-immunoreactive amyloid, very few IAPP-cells were seen despite a strong reaction of the B cells with antiserum to insulin. This study shows that IAPP is a normal islet B cell component and that IAPP immunoreactivity in $B$ cells is diminished in Type 2 diabetes while IAPP is deposited as amyloid fibrils in the islets of Langerhans. Although the function of IAPP is unknown, its occurrence in the islet $B$ cells and its structural relation to calcitonin gene-related peptide makes a hormonal nature probable. The present study indicates an altered expression or metabolic fate of IAPP in Type 2 diabetes.

Key words: Islet amyloid polypeptide, Type 2 (non-insulindependent) diabetes, insulin secretion, immunohistochemistry, islet B cell.
Type 2 (non-insulin-dependent) diabetes mellitus is a world-wide and prevalent disease whose pathogenesis is poorly understood. Deficient insulin release following a glucose stimulus is characteristic but peripheral insulin resistance has also been discussed as a primary defect $[1,2]$.

While the total islet mass is drastically reduced in Type 1 (insulin-dependent) diabetes, it is only moderately reduced in Type 2 diabetes [3-6]. The mass of B cells in Type 2 diabetes is about $50 \%$ as compared to normal controls $[5,7,8]$, but the reduction in volume of B cells alone cannot explain the diabetic state.

Deposition of a hyaline material in the islets of Langerhans in some cases of diabetes mellitus was described in 1900 [9]. Later, the hyaline deposits were shown to have the typical properties of amyloid, and are now regarded as a form of localised amyloidosis [10]. Subsequently, islet amyloid deposits were also found to be common in aging non-diabetic persons [7, $8,11,12]$. Quantitative data, however, indicate that the number of affected islets as well as the amounts of amyloid in the islets are generally much larger in Type 2 diabetes than in non-diabetic controls [7,8]. Even though infiltration of amyloid in the islets is associated with a loss of B cells $[7,8]$ and may also interfere with the diffusion of glucose and hormones, impairment of the islet function due to the deposition of amyloid may not be the only alteration involved in the pathogenesis of diabetes.

The close association of amyloid in islets to B cells [13] and the occurrence of amyloid in insulin-producing tumours has provided strong evidence that this type of amyloid is a product of B cells. It has therefore been suspected that amyloid in islets and insulinomas is derived from insulin or proinsulin. However, we recently found that the major protein in this type of amyloid is a previously unknown polypeptide which we identified as insulinoma or islet amyloid polypeptide (IAPP) [14-16]. Although unique, the amino acid sequence of IAPP has about 50\% identity to the neuropeptide calcitonin gene-related peptide (CGRP) [15]. This clarification of the nature of islet amyloid may also provide new insight regarding the pathophysiology of the islet derangements in Type 2 diabetes.

The aim of the present investigation was to study the occurrence and distribution of IAPP immunoreactive cells in the pancreas of human and several animal species, and to determine whether there is altered 
IAPP immunoreactivity in the islets of individuals with Type 2 diabetes.

\section{Material and methods}

\section{Tissues}

Pancreatic tissue from three human patients undergoing pancreatic resection due to carcinoma was used for the study of IAPP immunoreactivity in normal islets. These patients had no signs of metabolic disease and the morphology of the pancreatic tissue outside the tumour was normal. The specimens were immediately fixed in Bouin's solution and $4 \%$ formaldehyde, and embedded in paraffin. Specimens of pancreas, fixed in the same way, were also obtained from mouse, rat, guinea pig and hamster.

For the semiquantitative study (see below), pancreatic specimens from human patients were obtained at autopsies performed within $12 \mathrm{~h}$ after death. The pancreas was removed immediately after the abdomen was opened, and pieces of the pancreatic head, body and tail were fixed in Bouin's solution and 4\% formaldehyde solution and were then embedded in paraffin.

\section{Antisera}

An undecapeptide, with the sequence Cys-Ala-Thr-Gln-Arg-LeuAla-Asn-Phe-Leu-Val, corresponding to positions 7-17 of human IAPP $[14,15]$, was synthesised (Cambridge Research Biochemicals Ltd., Harston, Cambridge, UK) and linked to key hole limpet hemocyanin. Antisera were raised in a guinea pig (MA 50) and a rabbit (AA 82) by intracutaneous and subcutaneous injection of the conjugate $(0.3 \mathrm{mg})$ in Freund's complete adjuvant, followed by weekly injections of equal amounts of the IAPP conjugate in Freund's incomplete adjuvant. Serum was collected from the animals beginning at one week after the fourth immunisation. Guinea pig antiserum to insulin was obtained from Dr. L. Wide (Uppsala), and rabbit antiserum to rat CGRP was purchased from Milab (Malmö, Sweden).

\section{Immunohistochemistry}

Immunohistochemical studies were performed using the peroxidaseantiperoxidase (PAP) and biotin-avidin (ABC) (Vector Laboratories, Burlingame, Calif, USA) methods [17]. Deparaffinised sections of pancreas were initially incubated with the primary antisera in serial (1:50 to $1: 1,600)$ dilutions overnight at room temperature. The PAP and the $A B C$ techniques were subsequently performed with the primary antisera MA50 and AA82 diluted 1:200 and 1:600 respective1y. The insulin antiserum was diluted 1:1000 and the CGRP antisem rum 1:800. The reaction was visualised with 3,3 -diaminobenzidinetetrahydrochloride (DAB). In control experiments, the antisera were replaced by normal sera from guinea pig or rabbit. The specificity of the IAPP antiserum was also studied by absorption with the synthetic undecapeptide and with synthetic human insulin ("Humulin", Kabi-Vitrum, Stockholm, Sweden). For absorption, $100 \mu \mathrm{g}$ of substrate per ml of diluted serum was used. A sequential immunostaining and silver impregnation method, described in detail previously [18], was used for identification of the islet cells reacting with the IAPP antiserum. In other experiments, consecutive sections were stained with Grimelius' silver stain and immunostained for IAPP and for insulin.

\section{Semiquantitative study of IAPP in Type 2 diabetes mellitus}

Details regarding the two groups of patients included in this study are shown in Tables 1 and 2 . In the diabetic group, only patients with clinically confirmed overt Type 2 diabetes were included. The control group included subjects that had no clinical signs of diabetes and also had negative urine glucose tests.
Only pancreatic tissues without obvious autolysis, and with islets reacting with the anti insulin antiserum, were included in the study. Of the 33 patients from whom pancreatic tissue had been collected at autopsy, 9 were rejected, 7 due to weak or no insulin reactivity in the islets and one due to autolysis. One other patient had systemic amyloidosis, making quantification of islet amyloid impossible. Of the 24 remaining patients, 13 had Type 2 diabetes mellitus while 11 had no signs of this disease (Table 1 and 2).

Adjacent sections of pancreatic tail were used from each patient for staining with alkaline Congo red, and with the PAP method for the demonstration of insulin and IAPP. Only the rabbit antiserum AA 82 was used for this study. The percentage of islets containing any amyloid was determined in the Congo red stained sections using a polarisation microscope. All islets in the sections, irrespective of size, were included. The proportion of immunoreactive islet cells in entire sections stained for either insulin or IAPP were estimated using a semiquantitative scale: $0=$ no reactive cells, $1=<10 \%$, $2=10-50 \%$, and $3=>50 \%$ immunoreactive cells respectively.

\section{Results}

\section{IAPP distribution in normal human and animal pancreas}

Human pancreas obtained at surgery. Fixation with Bouin's solution was superior to formalin with regard to IAPP immunoreactivity when the guinea pig antiserum MA50 was used while the rabbit antiserum AA82 reacted equally good with either formalin or Bouinfixed material. A majority of the human islet cells showed a strong reaction with either IAPP antiserum. The intensity of cytoplasmic immunoreactivity was uniform from cell to cell. The staining pattern observed with IAPP antiserum was the same as with the anti insulin antiserum although the latter generally gave a stronger reaction (Fig. 1). Reactivity with the anti IAPP antiserum was confirmed to be limited to the B cells using the consecutively immunostained sections and the silver impregnation method. Argyrophilic cells (mainly A cells) were unreactive. A few islets contained only a few scattered IAPP cells, and by the sequential staining procedure these islets were demonstrated to consist mainly of A cells. In all normal pancreatic specimens, IAPP-positive cells without obvious connection with the islets were found among the exocrine acini. Occasional single IAPP immunoreactive cells were also present in the exocrine ducts. Absorption of the anti IAPP antiserum with the synthetic peptide and omission of the primary antiserum abolished the reaction with islet cells while absorption with insulin had no effect on the reactivity. Immunostaining with the CGRP antiserum resulted in a weak reaction with only a few islet cells. No further characterisation of these cells was performed.

Animal pancreas. IAPP immunoreactive cells were observed in the islets of Langerhans of the rat, mouse, guinea pig and hamster. In all animals, a majority of is" let cells were reactive, giving an intense reaction similar to that seen in normal human islets. The IAPP-positive cells in the rat, mouse, guinea pig and hamster 
Table 1. Percentage of islets with amyloid and estimated number of cells reacting with antisera to insulin and to IAPP in sections of the pancreatic tail of patients with Type 2 (non-insulin-dependent) diabetes

\begin{tabular}{|c|c|c|c|c|c|c|c|c|}
\hline \multirow[t]{2}{*}{$\begin{array}{l}\text { Patient } \\
\text { no. }\end{array}$} & \multirow[t]{2}{*}{ Sex } & \multirow{2}{*}{$\begin{array}{l}\text { Age } \\
\text { at } \\
\text { death } \\
\text { (years) }\end{array}$} & \multirow[t]{2}{*}{ Cause of death } & \multirow{2}{*}{$\begin{array}{l}\text { Duration } \\
\text { of diabetes } \\
\text { (years) }\end{array}$} & \multirow[t]{2}{*}{ Treatment } & \multirow{2}{*}{$\begin{array}{l}\text { Percentage } \\
\text { of islets } \\
\text { with amyloid }\end{array}$} & \multicolumn{2}{|c|}{$\begin{array}{l}\text { Immunoreactive cells } \\
\text { with antiserum to: }\end{array}$} \\
\hline & & & & & & & Insulin & IAPP \\
\hline 1 & $M$ & 81 & Myocardial infarction & 3 & $\begin{array}{l}\text { Unknown oral } \\
\text { antidiabetic drug }\end{array}$ & 42 & $3+$ & $1+$ \\
\hline 2 & M & 60 & Pulmonary emboly & Unknown & $\begin{array}{l}\text { Chlorpropamide }+ \\
\text { insulin for short } \\
\text { periods }\end{array}$ & 0 & $2+$ & $1+$ \\
\hline 3 & $F$ & 70 & Cardiac failure & 7 & $\begin{array}{l}\text { Chlorpropamide }+ \\
\text { insulin for short } \\
\text { periods }\end{array}$ & 30 & $3+$ & $1+$ \\
\hline 4 & $\mathrm{~F}$ & 69 & VOC and cardiac failure & 10 & Chlorpropamide & 91 & $3+$ & 0 \\
\hline 5 & M & 70 & Myocardial infarction & 10 & Chlorpropamide & 74 & $2+$ & 0 \\
\hline 8 & $\mathrm{~F}$ & 76 & Myocardial infarction & 12 & Glibenclamide & 68 & $3+$ & 0 \\
\hline 9 & $\mathrm{~F}$ & 70 & Myocardial infarction & 10 & $\begin{array}{l}\text { Chlorpropamide }+ \\
\text { phenformin }\end{array}$ & 53 & $3+$ & 0 \\
\hline 10 & $\mathrm{~F}$ & 70 & $\begin{array}{l}\text { Mammary carcinoma with } \\
\text { metastases }\end{array}$ & Unknown & Diet & 20 & $2+$ & 0 \\
\hline 11 & $\mathbf{M}$ & 63 & Myocardial infarction & 20 & Insulin & 99 & $2+$ & 0 \\
\hline 12 & $\mathrm{~F}$ & 77 & Lactic acidosis & 10 & $\begin{array}{l}\text { Glibenclamide + } \\
\text { phenformin }\end{array}$ & 98 & $3+$ & 0 \\
\hline 13 & $\mathrm{~F}$ & 81 & Cardiac insufficiency & Unknown & Unknown & 53 & $3+$ & $2+$ \\
\hline
\end{tabular}

$0=$ no, $1+=<10 \%, 2+=10-50 \%$, and $3+=>50 \%$ immunoreactive islet cells, respectively

Table 2. Percentage of islets with amyloid and estimated number of cells reacting with antisera to insulin and to IAPP in sections of the pan creatic tail of patients without signs of diabetes

\begin{tabular}{|c|c|c|c|c|c|c|}
\hline \multirow[t]{2}{*}{$\begin{array}{l}\text { Patient } \\
\text { no. }\end{array}$} & \multirow[t]{2}{*}{$\operatorname{Sex}$} & \multirow{2}{*}{$\begin{array}{l}\text { Age at } \\
\text { death } \\
\text { (years) }\end{array}$} & \multirow[t]{2}{*}{ Cause of death } & \multirow{2}{*}{$\begin{array}{l}\text { Percentage of } \\
\text { islets with } \\
\text { amyloid }\end{array}$} & \multicolumn{2}{|c|}{$\begin{array}{l}\text { Immunoreactive cells with } \\
\text { antiserum to: }\end{array}$} \\
\hline & & & & & Insulin & IAPP \\
\hline 1 & $\mathrm{~F}$ & 81 & Myocardial infarction & 0 & $3+$ & $3+$ \\
\hline 2 & M & 88 & Cardiac failure & 5 & $3+$ & $1+$ \\
\hline 3 & M & 79 & Myocardial infarction & 9 & $3+$ & $3+$ \\
\hline 4 & M & 58 & $\begin{array}{l}\text { Chronic glomerulonephritis } \\
\text { with uraemia }\end{array}$ & 11 & $3+$ & $3+$ \\
\hline 5 & M & 76 & Cardiac failure & 0 & $3+$ & $3+$ \\
\hline 6 & $\mathbf{F}$ & 56 & VOC and cardiac failure & 5 & $3+$ & $1+$ \\
\hline 7 & $\mathrm{~F}$ & 60 & $\begin{array}{l}\text { Myelogenic leukaemia }+ \\
\text { cerebral haemorrhage }\end{array}$ & 0 & $3+$ & $3+$ \\
\hline 8 & $\mathbf{M}$ & 59 & Myocardial infarction & 0 & $3+$ & $2+$ \\
\hline 9 & $\mathbf{F}$ & 90 & Myocardial infarction & 3 & $3+$ & $3+$ \\
\hline 10 & M & 73 & $\begin{array}{l}\text { Pulmonary tuberculosis } \\
\text { with respiratory insufficiency }\end{array}$ & 4 & $3+$ & $3+$ \\
\hline 11 & M & 83 & Myocardial infarction & 0 & $3+$ & $2+$ \\
\hline
\end{tabular}

$0=$ no, $1+=<10 \%, 2+=10-50 \%$, and $3+=>50 \%$ immunoreactive islet cells, respectively

were confirmed to be $B$ cells based on the consecutive sections stained with the argyrophilic method (Fig.2). Immunostaining with anti CGRP antiserum resembled that with the anti IAPP antiserum in the guinea pig, hamster and mouse. In rat islets, however, a few cells were strongly reactive while a major cell population gave a weaker reaction.

\section{Semiquantitative estimation of IAPP reactive cells in diabetic and non-diabetic adults}

Occurrence of islet amyloid. As seen in Table 1, all but one of the 13 diabetic patients had many islets with amyloid. The degree of amyloid infiltration was usually extensive. The amyloid had the typical staining 

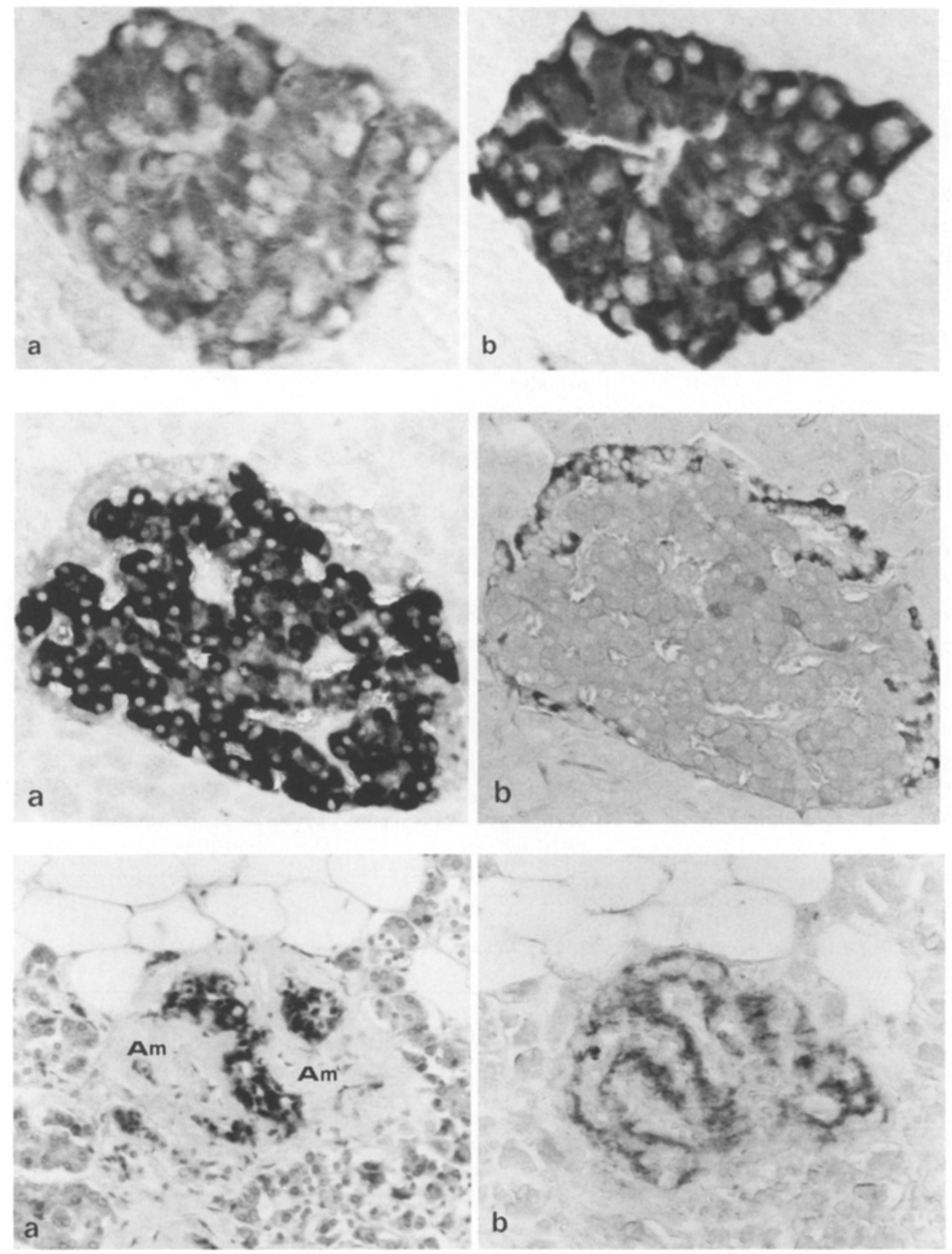

Fig.1a-b. Consecutively cut sections of human normal islet of Langerhans, immunohistochemically stained for a IAPP and $b$ insulin. The distribution of the immunoreactivity is virtually identical. $\times 370$

Fig. 2a, b. Consecutively cut sections of rat islet of Langerhans, immunohistochemically stained for a IAPP and b with the silver impregnation of Grimelius. The argyrophilic A cells do not react with antiserum to IAPP. $\times 220$

Fig.3a, b. Immunohistochemically stained islet of Langerhans from a patient with Type 2 diabetes. a The islet $B$ cells, but not the amyloid (Am), exhibit a strong reaction with antiserum to insulin. b When antierum to IAPP is used, the amyloid reacts, while the $B$ cells remain unstained. $\times 250$ properties and distribution as previously described (6-12). Six of the 11 non-diabetic patients also had deposits of amyloid in the islets (Table 2). However, fewer islets were affected and the amounts of amyloid in the individual islets were generally smaller as compared to diabetic patients.

Insulin immunoreactivity. In all pancreatic specimens from both groups of patients, a significant proportion of cells in the islets of Langerhans exhibited insulin immunoreactivity. The immunostaining for insulin was always strong and no certain difference in the intensity of reaction was detected between the B cells of the diabetic and non-diabetic groups. However, quantitative differences were apparent with respect to the number of insulin reactive cells in islets of the diabetic and non-diabetic groups. Four of the 13 diabetic patients had islets with only $10-50 \%$ of the cells giving insulin immunoreactivity (Table 1 ). B cells close to amyloid deposits were as strongly stained as B cells in apparently normal islets. The amyloid remained unstained in all sections (Fig. 3).

IAPP immunoreactivity. The percentage of islet cells with IAPP immunoreactivity in the non-diabetic group is given in Table 2 . All of the 11 non-diabetic individuals had islet IAPP immunoreactivity, and a majority of the islet cells reacted with the IAPP antiserum in 7 of 


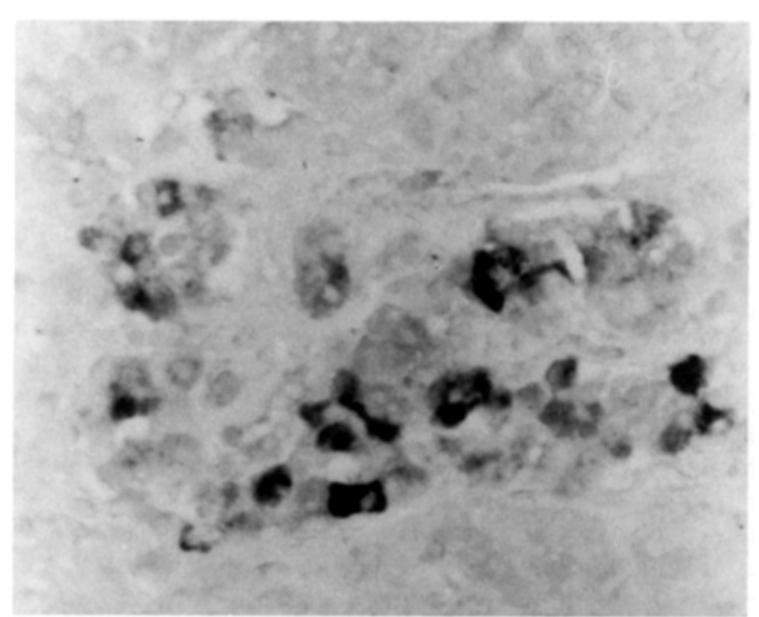

Fig. 4. Type 2 diabetic patients without islet amyloid. There is a remarkable reduction of the number of $B$ cells that react immunohistochemically with antiserum to IAPP. $\times 400$

the 11 patients. In these patients, the staining intensity in different cells was fairly uniform. These results are in sharp contrast to those of the diabetic patients (Table 1). Islets from only 5 of the 13 diabetic patients contained any IAPP-positive cells, mainly (4 of 5 patients) having less than $10 \%$ of cells with IAPP immunoreactivity. In those islets where IAPP immunoreactivity was found, the staining intensity varied greatly with some cells exhibiting very strong reaction while others were only weakly positive. In both diabetic and nondiabetic patients, islets with amyloid usually contained no IAPP-positive cells in spite of a strong insulin immunoreactivity in the B cells (Fig. 3). In only one patient (no.13, Table 1) IAPP-positive cells were found together with amyloid deposits. Islet amyloid of both diabetic and non-diabetic patients reacted strongly with the antiserum to IAPP (Fig. 3).

\section{Discussion}

Deposition of amyloid, although not pathognomonic, is the single most typical alteration in the islets of Langerhans in Type 2 diabetes mellitus. The obvious lack of interest in this substance by scientists working in the diabetes field may seem strange but is probably partly related to the fact that experimentally-induced diabetic animals do not develop islet amyloid.

The fibril proteins of amyloid localised to one organ or tissue are believed to be synthesised close to the deposits [19]. Previous electron microscopic studies of the amyloid of the islet of Langerhans have indicated that the islet B cells are likely to be responsible for the production of this type of amyloid [13]. Since the amyloid in the $\mathrm{C}$ cell tumour of the thyroid consists of a calcitonin-related protein, probably procalcitonin [20], it has seemed logical to assume that islet amyloid contains an insulin- or proinsulin-related protein. In fact, amyloid-like fibrils are easily formed synthetically by insulin [21, 22] and a weak insulin B-chain reactivity has been demonstrated in islet amyloid [23]. On the other hand, islet amyloid does not react immunohistochemically with antibodies to insulin [23]. In a recent study, we showed that the amyloid fibrils in an insulinproducing pancreatic tumour mainly consisted of a previously unknown polypeptide which we designated insulinoma or islet amyloid peptide, IAPP [14]. Subsequently we have shown that IAPP is a major constituent of islet amyloid peptide, IAPP [14]. Subsequently we have shown that IAPP is a major constituent of islet amyloid in man and cat $[15,16]$. This composition of islet amyloid has recently been confirmed [24]. IAPP, at least in its amyloid forms, consists of 37 amino acid residues and has almost $50 \%$ identity with the neuropeptide CGRP [15].

The present study has shown IAPP immunoreactivity in the B cells of apparently normal human pancreatic islets and also in B cells of rat, mouse, guinea pig and hamster. These results indicate a wide occurrence of the peptide in several mammalian species. Since IAPP structurally resembles CGRP, it is of interest that CGRP immunoreactivity previously has been described in islet cells of the rat and mouse [25], a finding also confirmed in the present study. It cannot be ruled out that some of these findings are due to a cross reactivity of CGRP antibodies with IAPP although the presence of both polypeptides is also possible. It should be noted that CGRP antibodies labelled only a few human islet cells weakly and did not bind to islet amyloid, although such immunoreactivity recently has been reported [24].

Most of the diabetic human patients in this study had advanced islet amyloid deposits in contrast to the material of non-diabetic patients. Islet amyloid deposits in non-diabetic patients were present but to a much lesser extent. The fact that islet amyloid occurs in many non-diabetic elderly patients, however, may also indicate some abnormality in their islets. The reduction of the number of IAPP-immunoreactive cells in the islets of some non-diabetic patients may support this theory. Furthermore, the most obvious reduction of IAPP immunoreactive cells was found in two patients (no.'s 2 and 6, Table 2) in whom islet amyloid occurred.

As compared to non-diabetic patients, there was a pronounced reduction of IAPP-reactive cells in the islets of Type 2 diabetic patients. Some (but much smaller) reduction of the number of insulin-containing cells was also evident. Islets with amyloid, both in diabetic and non-diabetic patients, usually did not contain any IAPP immunoreactive cells.

Our data indicating decreased number of IAPP immunoreactive cells in Type 2 diabetic patients is based on evaluation of human pancreatic tissue obtained from routine autopsies. Certain limitations are obviously inherent to the use of autopsy material but they were considered in the experimental design and inter- 
pretation of results in the present investigation. Surgically resected human pancreata from three patients without clinical evidence of metabolic disease were immediately fixed and used as positive controls for IAPP and insulin immunoreactivity. Only pancreatic tissues without evidence of autolysis and with insulin immunoreactivity were used for the semiquantitative study. Although variations with respect to death-to-autopsy time interval and length of tissue fixation are inevitable with the tissue specimens used in this study, the variables in the two groups should be random and thus should not significantly affect the comparison of the islet tissue from diabetic patients with that from the nondiabetic patients. Prospective studies utilising cats provide an opportunity to perform studies like this under more optimal conditions [26].

These findings suggest that there is an altered production or metabolism of IAPP in Type 2 diabetes that is in some way linked to the formation of islet amyloid. The lack of cellular IAPP in islets with amyloid may appear contradictory to this scenario, but formation of amyloid from IAPP or a related IAPP-precursor is likely a progressive process that may eventually be associated with IAPP depletion.

Since IAPP is apparently localised to the islet B cells, a decrease in the number of these cells due to any cause would be reflected by a deficit of IAPP. This is certainly most relevant in juvenile (Type 1) diabetes, where B cells are virtually totally destroyed. The pathogenic importance of decreased IAPP in either form of diabetes is not yet known, and new studies must be initiated to determine the function of IAPP in normal humans and animals.

Acknowledgements. Supported by the Swedish Medical Research Council (Projects Nos.5941 and 6817), the Research Fund of King Gustaf V, the Nordic Insulin Fund, and Grant No. RO1 OK36734 of the National Institute of Diabetes and Digestive and Kidney Diseases.

\section{References}

1. Efendic S, Cerasi E, Elander I, Thornqvist C, Fick G, Berglund B, Luft R (1979) Studies on low insulin responders. Acta Endocrinol 90 [Suppl]: 224

2. O'Rahilly SP, Nugent Z, Rudenski AS, Hosker JP, Burnett MA, Darling P, Turner RC (1986) Beta-cell dysfunction, rather than insulin insensitivity, is the primary defect in familial type 2 diabetes. Lancet II: $360-364$

3. Maclean N, Ogilvie RF (1959) Observations on the pancreatic islet tissue of young diabetic subjects. Diabetes $8: 83-91$

4. Gepts W (1965) Pathologic anatomy of the pancreas in juvenile diabetes mellitus. Diabetes 14: 619-633

5. Maclean N, Ogilvie RF (1955) Quantitative estimation of the pancreatic islet tissue in diabetic subjects. Diabetes 4: 367-376

6. Warren S, LeCompte PM, Legg MA (1966) The pathology of diabetes mellitus, 4 edn. Lea \& Febiger, Philadelphia

7. Westermark P, Grimelius L (1973) The pancreatic islet cells in insular amyloidosis in human diabetic and non-diabetic adults. Acta Pathol Microbiol Immunol Scand [A] 81: 291-300

8. Westermark P, Wilander E (1978) The influence of amyloid de- posits on the islet volume in maturity onset diabetes mellitus. Diabetologia 15: 417-421

9. Opie EL (1900) On relation of chronic interstitial pancreatitis to the islets of Langerhans and to diabetes mellitus. J Exp Med 5: 397-428

10. Ehrlich JC, Ratner IM (1961) Amyloidosis of the islets of Langerhans. A restudy of islet hyalin in diabetic and nondiabetic individuals. Am J Pathol 38: 49-59

11. Bell ET (1959) Hyalinization of the islets of Langerhans in nondiabetic individuals. Am J Pathol 35: 801-805

12. Melato M, Antonutto G, Ferronato E (1977) Amyloidosis of the islets of Langerhans in relation to diabetes mellitus and aging. Beitr Pathol 160: 73-81

13. Westermark P (1973) Fine structure of islets of Langerhans in insular amyloidosis. Virchows Arch [A] 359: 1-18

14. Westermark P, Wernstedt C, Wilander E, Sletten K (1986) A novel peptide in the calcitonin gene related peptide family as an amyloid fibril protein in the endocrine pancreas. Biochem Biophys Res Commun 140: 827-831

15. Westermark P, Wernstedt C, Wilander E, Hayden DW, O'Brien TD, Johnson KH (1987) Amyloid fibrils in human insulinoma and islets of Langerhans of the diabetic cat are derived from a novel neuropeptide-like protein also present in normal islet cells. Proc Natl Acad Sci USA 84: 3881-3885

16. Westermark P, Wernstedt C, O'Brien TD, Hayden DW, Johnson KH (1987) Islet amyloid in type 2 human diabetes mellitus and adult diabetic cats contains a novel putative polypeptide hormone. Am J Pathol 127: 414-417

17. Sternberger LA (1979) Immunocytochemistry, 2nd edn. John Wiley \& Sons, New York

18. Lundqvist $M$, Wilander $E$ (1983) A simple procedure for immunocytochemical- and silver-staining of endocrine cells in the same section. Acta Pathol Microbiol Immunol Scand [A] 91: 493-494

19. Westermark P, Cornwell GG III (1986) Varied composition and nature of senile localised amyloid: implications for varied mechanisms of pathogenesis. In: Glenner GG, Osserman EG, Benditt EP, Calkins E, Cohen AS, Zucker-Franklin D (eds) Amyloidosis. Plenum, New York, pp 659-668

20. Sletten K, Westermark P, Natvig JB (1976) Characterization of amyloid fibril proteins from medullary carcinoma of the thyroid. J Exp Med 143: 993-998

21. Glenner GG, Eanes ED, Bladen HA, Linke RP, Termine JD (1974) $\beta$-pleated sheet fibrils. A comparison of native amyloid with synthetic protein fibrils. J Histochem Cytochem 22: $1141-1158$

22. Westermark P (1974) On the nature of the amyloid in human islets of Langerhans. Histochemistry 38: 27-33

23. Westermark $P$, Wilander $E$ (1983) Islet amyloid in type 2 (non-insulin-dependent) diabetes is related to insulin. Diabetologia 24 : 342-346

24. Clark A, Cooper GJS, Lewis CE, Morris JF, Willis AC, Reid KBM, Turner RC (1987) Islet amyloid formed from diabetes-associated peptide may be pathogenic in type- 2 diabetes. Lancet II: 231-234

25. Pettersson M, Ahren B, Böttcher G, Sundler F (1986) Calcitonin gene-related peptide: occurrence in pancreatic islets in the mouse and the rat and inhibition of insulin secretion in the mouse. Endocrinology 119: 865-869

26. Johnson KH, Hayden DW, O'Brien TD, Westermark P (1986) Spontaneous diabetes mellitus-islet amyloid compex in adult cats. Am J Pathol 125: 416-419

Received: 25 March 1987

and in revised form: 10 September 1987

Dr. Per Westermark

Department of Pathology

University Hospital

S-751 85 Uppsala

Sweden 